\title{
Notes on Ashanti
}

\section{Major C. Barter}

To cite this article: Major C. Barter (1896) Notes on Ashanti, Scottish Geographical Magazine, 12:9, 441-458, DOI: $10.1080 / 00369229608732910$

To link to this article: http://dx.doi.org/10.1080/00369229608732910

册 Published online: 27 Feb 2008.

Submit your article to this journal שك

LII Article views: 8

Q View related articles ¿ 


\title{
THE SCOTTISH
}

\section{GE O G R A P H I C A L}

\author{
MA G A ZINE.
}

\section{NOTES ON ASHANTI.}

By Major C. Barter,

Second-in-Command, Special Service Corps, Ashanti Expedition, 1896.

(Read before the Society in Edinburgh on May 7th.)

When the Royal Scottish Geographical Society did me the honour to ask me to deliver a lecture on my experiences in Ashanti during the recent expedition, I warned their esteemed Secretary that the most I could offer, outside the military features of the campaign, would be a record of general impressions and of the local accounts and traditions which my memory had retained.

If with these disconnected notes of a personal observer I should have the good fortune to interest you at all, I must in fairness attribute a large share of the merit to a charming companion of our march, Canon TaylorSmith, of Sierra Leone, who was attached to the Special Service Corps as chaplain, and who followed all its fortunes. Canon Taylor-Smith, in the course of his good work throughout several years in these regions, had acquired a vast fund of information on all points connected with them. When during the long hours of early march, or in camp under our hastily raised shelter of palm or plantain leaves, I listened to his interesting descriptions of the country and its people, I little thought that I should shortly be serving as his unworthy mouthpiece before a distinguished audience in Edinburgh. Having made this just acknowledgment, I will now pass to the subject-matter of my discourse; but as there appears to have existed a good deal of misapprehension in the mind of the public generally regarding the real causes that led to the despatch of the recent expedition, allow me, very briefly, to retrace the historical events which have now culminated in the complete subjugation to British power of the once mighty and dreaded Ashanti kingdom.

voL. XII. 
Since the commencement of the present century, the tribes on the coast line, of which the principal is the Fanti race, have been subjected, sometimes with only brief intervals of quiet, to the savage and desolating incursions of their warlike northern neighbours, the Ashantis.

As the Fantis and other tribes of the coast, in whose territories we had formed settlements, were our allies, we did what we could, sometimes by force of arms with inadequate means, and sometimes by remonstrances or by diplomatic action, to assist the nations who were friendly to us. Our efforts were not always successful, as the well-known disaster to Sir Charles Macarthy's force, early in the century, proves, nor was the action of the British authorities in the colony always judicious or well-timed. Be that as it may, the Ashantis on more than one occasion carried fire and sword to the very walls of the British forts on the coasts.

Our Gold Coast Protectorate was finally established in 1852, and extended to the river Prah, and for two decades peace was restored. But in 1873 fresh trouble arose. The Ashantis came down with large forces as far as the coast. Trade with the interior was entirely stopped, owing to the cruel and rapacious behaviour of the Ashantis, and the friendly tribes of the coast were decimated and terrorised, large numbers being carried off to slavery or sacrifice. So menacing was the attitude of the Ashantis, that it became necessary to decide whether the British settlements on the Gold Coast should be entirely abandoned, or the invaders driven back by a large British force, to be despatched from England.

As a result of the selection of the latter course, Sir Garnet Wolseley, in the beginning of 1874, after some severe fighting, occupied and destroyed Kumassi, which had been evacuated by the Ashantis. In the end peace was concluded by the Treaty of Fomanah, the principal conditions imposed on King Kofi of Ashanti being-

An indemnity of 50,000 ounces of gold.

Freedom of trade in Ashanti.

The abolition of human sacrifice.

The maintenance of a good road from Kumassi to the Protectorate.

From the date of this treaty, taught, no doubt, by costly experience, the Ashantis almost totally abstained from molesting our Fanti allies; but the non-observance by the Ashantis of the other conditions of the compact, and especially their continued and increasing interference with the important carrying trade through Kumassi, led to frequent representations being made to them by the British authorities on the Gold Coast-representations which were treated by the Ashanti rulers with ever-increasing contumely as they saw that the official admonitions were never sustained by force. Finally, last year, a mission which went to Kumassi under Captain Donald Stewart, with an escort of Houssa police, was treated with scant courtesy, and the escort was attacked on the way back, one of the Houssa police being killed. As the King of Kumassi continued to offer nothing but the same vague and ineffective promises, without attempting to put an end to the abuses complained of, it was finally decided to send out an expedition, not necessarily with the object of waging war upon the Ashanti people, but for the purpose of enforcing suitable conditions for the permanent establishment of a just and humane 
government in the country, and for the protection of the legitimate trading operations of Gold Coast Colony-operations which were practically impossible so long as the Ashantis maintained their attitude of sullen hostility and menace.

It is unnecessary for me to recall events of very recent date, or to enter into a detailed description of the military features of the expedition. Suffice it to say that it was excellently organised and equipped in England, the health and comfort of the force being minutely considered. Large and commodious transports were provided for the conveyance of the troops from England to the Coast, and the hospital ship stationed off Cape Coast Castle contained every arrangement and every appliance which could be i devised for the wellbeing of the sick and wounded. On the Gold Coast If itself, before the arrival of the force, Governor, now Sir William, Maxwell $\Xi$ had by untiring efforts succeeded in collecting from every available source, ¿ extending as far even as Sierra Leone, a veritable army of native carriers, N numbering some 15,000; and to this fact, as well as to the able conduct $\stackrel{m}{m}$ of the expedition, must be attributed the rapid and highly successful issue of the campaign.

I regret that I can only give a very brief and general geographical Doscription of Ashanti itself; but if time allows of my doing so, I propose $\because$ to offer, later in the lecture, a few notes which I have collected on the immediate Hinterland of Ashanti.

Aू Ashanti, which, as you will see on the map, is situated a few degrees of only to the north of the Equator, is essentially a forest kingdom, and lies Entirely within the belt of primæval forest which extends for over a thousand miles along this part of the west const of Africa. The forest, a If part only of which is occupied by Ashanti, has a breadth of about 300 miles. The surface of the country, except in isolated hilly districts of small area, is undulating, the water-courses being generally broad and of a swampy character. Save where human hands have made a clearing, the forest, dense and tangled, everywhere covers the face of the land. The southern boundary of the Ashanti kingdom is the river Prah, which separates it from the sphere of Gold Coast Colony. To the north, the limit of Ashanti power has been the forest edge, some six marches north - of Kumassi. Here begin rich prairie plains with a healthy climate and Ean abundance of big game; but these districts are under the dominion of Oूthe great chief Samory, who rosie from the position of slave to be sultan, Fand now rules practically over the vast district which extends from the Coast Kingdoms to Timbuctoo. He it was who lately defeated the French expedition under Monteil, but who refused, it is said, probably with truth, to join the Ashantis against the British.

The kingdom of Ashanti is, or rather has, up till recently, been composed of a realm of seven provinces, each ruled over by a king or great chief. These provinces in the order of their importance are Kumassi, Kokofu, Juabin, Mampon, Beckwai, Insuta, and Adansi. The King of Kumassi has, as far as is known, always been the paramount chief; but the presence of the other six chiefs at his "stooling," or installation as King of Ashanti, has always been legally indispensable. In the case of Prempeh the formality had never been gone through, so that he was really 
only King of Kumassi. He possessed, however, a controlling power undoubtedly greater than that of any of the other ruling kings.

It is impossible to offer a correct estimate of the population of the collective Ashanti kingdoms, but it lies probably between 150,000 and $200,000$.

From a military point of view the outcome of the march to Kumassi was, of course, disappointing, as the Ashantis offered no resistance to the advance of the British force and the occupation of Kumassi ; but considering the question from a broader and more humane standpoint, it must be a matter of congratulation that the desired end was attained without the unnecessary loss of British lives, and without the inevitable slaughter of jgnorant savages, a slaughter which would have been great in proportion to the bravery of our adversaries.

Nor can it well be denied that the ulterior objects of peaceful administration and development are best furthered by the firm display of force, not accompanied by the stern necessities of war, but by the tempering influences of a Christian-like civilisation.

I have seen it more than once stated that the expedition was unnecessarily strong in its composition, and that a heavy hammer was employed to crack a nut; but I think it hardly doubtful that if a weak force had been sent, bloodshed would have resulted, for the Ashantis are a warlike and courageous race, and fought with great bravery against us in the last campaign, though the force then employed was considerably stronger than that which marched into Kumassi in January last.

In Ashanti, however, we found, in the result, that the nation's power had greatly suffered both in actual strength and in prestige by its defeats in the campaign of 1874 . There were plenty of fighting men, no doubt, and there existed in favour of war a very strong party, which included the fetich priests and some of the greater chiefs; but many of the older people still lived to remember the disastrous past and offer wiser counsels of peace. Two or three Ashantis had, further, visited England, and the tales of their travels must have convinced the king and his advisers that resistance would in the end be hopeless. Besides this factor in favour of peace, there was, I am sure, another and very powerful one. In olden days before 1874, the wars waged, invariably successfully, by the Ashantis against neighbouring nations had provided them with a never-failing supply from outside of slaves and victims for sacrifice. After their defeats by the British force, fear of retribution kept them from openly raiding those tribes surrounding them who had come more or less under our protection. But victims to fetich rites had still to be found, for the cruel custom of human sacrifice flourished as before, and there followed a constant drain from amongst the Ashantis themselves. The chiefs were called upon to furnish contingents of victims. They selected their enemies and the least influential natives. One poor old woman, whom we questioned in a village not far from Kumassi, informed us through the interpreter that she was alone in the world. She had had three sons; they had all been taken for fetich sacrifice. I believe the people were sick of the custom. Around them they beheld tribes who by treaty with civilised nations were prohibited from offering human lives to fetich, 
yet the wrath of the evil spirit had not been visited on these. They flourished without the practice of decimating human oblations. I am convinced that a large proportion of the Ashanti people silently welcomed our approach, dreading only the vengeance of the native allies who accompanied us, and who for centuries had suffered from their pitiless aggression.

The combatant portion of the British force landed on the 28th December, and at once began its march inland. The first day's march, owing to the necessity of disembarking by daylight in surf boats, was in the afternoon, and very trying it was in the hot, damp atmosphere, though every effort was made to make the march easy for the men. For twenty miles inland the road lies through a sandy, undulating country, covered with scrub and low bush, affording no protection from the rays of a tropical sun. I think one of our youngest officers here aptly expressed his discomfort when he said that it was hot enough to make a sponge-cake perspire. After the first day, however, a start was always made at night or early in the morning, and the troops arrived in camp before the sun had risen much above the horizon. Ten miles or so from the coast we came upon the first trees, standing like sentinels of the great forest, watching our approach. 'Thicker and thicker they became, until, twenty miles from the coast, we reached the vast primæval forest itself. Never shall I forget our first plunge into its depths. We started at midnight, as the bells in England were ringing in the New Year, and more than one mind must have instituted a striking comparison between the merry sounds and the brightness at home, and the deadly gloom of the dark forest in front of us. Entering it suddenly at night from the open moonlit space which held the village where we had camped, the arched opening above the path seemed to form the entrance of a vast dungeon, and as I looked up I half expected to read overhead the inscription imagined by Dante over the gates of the infernal regions- "All hope abandon, ye who enter here." And so it must have often seemed to the poor captive who was being led back to Kumassi to slavery or execution.

It is really hard to accurately describe the first sensations of a march in the night through this dark forest. A thick vapour, which not a breath moves, covers the forest to the apex of the highest trees which, when they can be seen, tower over 200 feet overhead, and so heavy is the dew that the leaves are dripping as after a heavy shower. There is no silence in the forest. A thousand noises strange to the white man's ear assail it on every side from myriads of members of unseen animate life, and above all dominates the ceaseless hissing trill of the crickets, whilst at intervals up in the trees is heard the complaint of the sloth, which, beginning with a pitiful sound of pain, traverses the whole gamut until its wail forms the most weird and discordant screech that it is possible to conceive. All are subject to the depression caused by the heavy, illsmelling atmosphere, charged with damp and the odour of decaying vegetable matter, and the feeling is accentuated when the night is moonless and the narrow and treacherous path dives down into one of the swampy valleys where the bamboo clumps grow thick, excluding all light 
from above. Suddenly morning breaks. The light comes with a rush, and all is changed. The vapour cloud rises from the saturated litter which forms the forest bed, and seems to lift with it the oppression which weighs down the human mind. The unseen birds far up in the topmost branches break forth in song, and Tommy Atkins, a veritable child of nature, echoes the birds' reveille. There is music in the air, and the pace becomes brisker, as though it were a return from a military funeral.

At this hour the forest is grand and beautiful in the extreme. The leaves are covered with dew, and every atom of wet shines in the morning light. It is a vast conservatory, filled to profusion with the richest tropical plants. The undergrowth is extremely dense, the intertwining of vines and the stems of plants offering a very wall to any advance. In many places a passage through can only be attained by arduous cutting. 'The luxuriance of vegetable growth, under the existing conditions of soil and climate, cannot well be imagined. As an instance, I may state that I have seen places which had been cleared absolutely to the ground covered three weeks later by growths higher than a man's head. This very luxuriance is the cause of the long-drawn height of all trees and plants. Each is stretching upward to the light in its response to the natural law of the survival of the fittest. It is very human in its aspect, this struggle of the plants for light. The strongest tribes push their way upward, regardless of the way in which they prejudice their weaker brethren, till they reach the light of day, far up, and parasite creepers that have profited by the rise of the giants send down their offshoots to feed on the earth below.

Some of these vines are remarkable for their perfect symmetry of form, and give a very accurate representation of carefully twisted strands. Some of them hang down, straight as a plumb-line, a stretch of over one hundred feet, and look like the cable hawsers of ironclads at anchor.

Perhaps the most striking forest effect is that presented in the bamboo groves, down in the low ground bordering the stagnant pools and oozing streams. The bamboos grow to the thickness of a man's leg, in immense solid clumps set wide apart. Overhead, some fifty feet, they form beautiful Gothic arches, sometimes of remarkably regular vaulted appearance. At night, when the grove is lit up by fires, the architectural effect is heightened, and the picture afforded by the red glow, which makes the surrounding objects stand out against the inky darkness behind, is extremely beautiful.

Every two or three miles the path leads to a clearing in the forest, where grow the trees and plants on which the natives' existence dependsthe plantain and banana, the papaw, some cocoa-nut trees, and patches of yams. In the centre of the clearing is the village, the houses of which are all made of red or yellow mud with roofs of closely knitted branches or vines. Every habitation is built on the same design, only the extent of the habitation varying with the importance of the owner. Each has an entrance at one of the angles of the building, leading to a square courtyard round which are four rooms, all without walls on the inside, and therefore open to the court. The floor of the rooms is raised two or 
three feet above the soil, and is reached by one or two steps. In the houses of the chiefs there are two or more courtyards opening at one of the angles into each other, and the houses are larger, but all have a regular entrance to the front, and another, a bolt-hole really, in rear.

In the courtyard are mud cones forming the fireplace, and either in the centre, or along one of the walls, is generally to be found a stake, on the top of which is placed a bowl containing an offering to fetich-palm oil, decayed eggs, or a decomposed chicken. These fetich emblems are held in great respect; and some of the officers' native servants, even amongst those brought up in the comparative civilisation of the coast, could not be persuaded to remove these unsavoury objects of superstitious veneration.

Each village has at least one tree which is held sacred, partly, no doubt originally, owing to the grateful shade which it affords. Under its branches lie roughly hewn trunks of trees on which the natives squat and hold council, which they appear to do all day long when they are not engaged in eating or sleeping.

Travelling on through the forest along a path which, as far as the Prah, is of fair width in most places, and along which generally two and sometimes four men can walk abreast, the river Prah is reached, about seventy-four miles from Cape Coast Castle, and just half-way to Kumassi. The Prah is the sonthern boundary of Ashanti, and is looked upon as a sacred river by the natives. It has always been crossed with great reluctance by the Fantis and other southern tribes, who all lived in mortal fear of the Ashantis beyond ; and we witnessed the incantations of several groups of natives, who would not move on from the farther bank until they had fired guns and sung prayers to propitiate the spirit of the river. Having finished the ceremony, they dashed forward in the direction of Kumassi with every appearance of zeal and reckless courage, but their active gait soon showed sign of flagging, and it is more than doubtful whether the appearance of one armed Ashanti would not have sent the whole party flying back.

From the Prah to Kumassi the path becomes very narrow, and often rough, and the men were often obliged to march in Indian file. The features of the forest are here still the same, save when the Adansi hills are reached, forty miles from Kumassi. The path crosses the crest of these hills at a height of 1100 feet, and at last, after many days, we breathed fresh, pure air again, but not for long, as the path descends again abruptly on the northern slope. This group of hills, the only one of any importance in this part of the country, will, probably, as the development of the country progresses, become a sanatorium, or "hill station," as it is called in India, for the whole district, or it may be made into a military station for some Houssa companies. A little farther, at Essian $\mathrm{K}$ wanta, we witnessed an interesting ceremony. The King of Beckwai met the commander of the force, Sir Francis Scott, in solemn palaver to conclude a treaty, which placed his kingdom under British protection. A great show this potentate made as he passed through our camp, carried on a brass chair, under an immense umbrella of many 
colours, preceded by his band of tomtoms and ivory horns, and attended by minor chiefs; and when in the open place in the village he sat on his throne, surrounded by his principal chiefs in rich cloths, and his "doctors" and executioners in weird attire, the group formed was very interesting and picturesque. On his right sat his "chief linguist," or principal adviser, a cunning and sly-looking old savage, with a dignity of manner and calmness of speech which many a politician at home would be glad to possess. The negotiations did not last long. The King had crossed the Rubicon, and now had to stand or fall with us. But the terms were fair and just and readily agreed to-only on one point did the king and his minister make an obstinate stand. It was on the question of human sacrifice. By every subterfuge did they endeavour to obtain the insertion of a clause which might have served as an excuse for human sacrifice to fetich. But the strict rule which laid down that capital punishment could be inflicted only by sentence of a proper British tribunal was immutable, even for the crime of "lèse-majesté" against the persons of the King or his wives.

The submission of the King of Beckwai, one of the principal chiefs of Ashanti, left little doubt that the expedition would meet with no resistance, and we pushed on rapidly to Kumassi, which we entered on the 17th January, after crossing the sacred river Adra. As we neared the capital we found our path strewn with emblems of fetich, rough human figures carved in wood, goat-skins, dead chickens, and other symbols, probably, which we did not notice. These signs all had a meaning, though we did not understand them. Some of the interpreters declared that they were peace-offerings, and so they must have been, judging by the result. The Ashantis had decided not to fight, but King Prempeh had determined to offer us a brilliant reception; and as we marched up the great market-place in the centre of the town, we found him sitting in great state, surrounded by a great crowd of chiefs and courtiers in brilliant array, but all unarmed. Along the sides of the square were the lesser kings and chiefs, all seated under coloured umbrellas, on chairs of size and quality suited to their respective ranks. Thus a small chief had a very small chair with a minimum of brass ornament and a small black umbrella, generally in very poor condition and with some of its ribs sticking out, while the kings were covered by huge umbrellas of velvet and silk, and sat on larger chairs covered with brass plates and nails. From every group rose an incessant din from savage musical instruments, the tomtoms especially sustaining the character of the orchestra with emphasis. With regard to these drums we were informed that there exists a perfect system of signals which allows of orders being rapidly transmitted in the forest, so that in war messages can be passed on with great ease and rapidity. We were told that every one of the apparently aimless beats which we heard formed part of a code which the natives could perfectly understand.

Of Kumassi itself there is not very much to tell, for its ancient glory was much shorn by the events of the war in 1874. It stands for the greater part on a plateau 400 to 500 feet above the level of the sea. It is a town in size, but it bears the character of a village throughout. 
It stands in a large open space about one mile in diameter, and is surrounded by the dark forest. The so-called palace is a very poor affair, and consists of a succession of courtyards surrounded by high mud walls, which contain the rooms I have already described for the ordinary houses. The King's wives were lodged on the other side of a lane which the palace forms with a long narrow building where the ladies lived. Each wife had a room upstairs, each room being separate, and reached only by a narrow staircase from below. To each room was a small window opening on the lane. The ladies were, I was informed, very strictly guarded, and I may here state that when the King's wives took their walks abroad they were preceded by a court crier, who gave notice of their approach. As they passed, the people knelt with averted faces in the dust, for to look on them was death for a man.

By far the most commanding and interesting feature of Kumassi, a name which in Ashanti means the place of sacrifice, is the sacred grove, the Golgotha of the place, where the bodies of the victims to fetich were thrown to feed the vultures. This grove, especially when seen from some little distance, offers a magnificent specimen of Nature's gardening. It stands on the highest ground in the town, and is composed of a great variety of beautiful trees. The cotton-trees, with a girth at base of 40 to 50 feet, and as much as 250 feet high, tower above the others. Some graceful and tall palm-trees with plumed summits give lightness to the group; while below, close to the ground, the dark depths beneath the boughs suggest that Nature is trying to cover the crimes of humanity. Entering the grove, the soil is at once seen to be littered with the remains of thousands of human bodies. The character of the soil in places is changed by the dust of the crumbling bones, and skulls of every age lie about under the trees in hundreds. Busy in this gruesome spot might be seen our native allies, extracting the front teeth from the skulls to wear as charms, which are supposed to bring much good luck.

Before we left Kumassi the engineers had ruined the beautiful aspect of the grove to a large extent by blowing down the larger trees with gun-cotton, but this proceeding was necessary in view of its effect on the superstitious mind of the natives.

To the north of Kumassi, and about a mile from it, were situated the temples of Bantama, the home of Ashanti fetich, and the resting-place of the kings. The word temples must be taken here to describe the object of the buildings, and not their outward character, for they consisted merely of ordinary courtyards and houses, in some of which were stored the remains of the Ashanti rulers. I may mention that when a king dies he is first buried, or rather stored, in a special house in Kumassi. At the end of one year his bones are cleaned, bound together with gold, and then taken to Bantama. Great chiefs when they die are thrown into a sacred stream which runs not far from the town. It had been rumoured that the temples held great treasures. If so, the priests must have removed them before our arrival, for not a thing of value was found. The priests fled on the approach of the troops, and the temples were burned and their walls thrown down.

An interesting feature on the road in front of the temples was the 
sacred fetich tree of Kumassi, a fine banyan, affording tempting shade to the unwary traveller, who invariably paid the penalty of sitting under its branches with death. Still lying under the tree was found the large copper basin which received the blood of the victims who were decapitated at the frequent sacrifices which attended the visits of the king to the tombs of his forefathers. Beneath the mound on which the bowl rested the soil was black with the blood of years.

Each quarter, it is said, the King visited Bantama, and from twenty to thirty victims were put to death. As a rule, torture was'not resorted to ; but when the necessary licence was given to the executioners, they vied with each other in refinements of savage cruelty.

Apart from the victims procured by raids or by contributions from dependent chiefs, others were furnished through the commission of specified crimes and misdemeanours. It was said, for instance, that any native finding a nugget of gold, and not at once forwarding it to the King, was condemned to death. In the same manner, every man who found any article of value on the market square, and did not deliver it up at the King's palace, forfeited his life. There appear, however, to have been certain saving clauses. A man arrested could save his life by rapidly reciting a formula containing the King's name, or if by running he could reach a certain spot before being caught, he went free. But the offender or victim really had little chance of escape. He was generally pounced upon, his hands instantly bound behind his back, and a knife stuck from cheek to cheek through his mouth to prevent him from uttering the redeeming formula.

At sundry festivals, notably that of the Yam, human sacrifices were indispensable, and at the death or coronation of a king a thousand victims were often offered in sacrifice. The death of even a minor chief always involved the execution of a number of slaves.

The stay of the British portion of the force at Kumassi was shortonly three days-but events marched rapidly, and with the great palaver and the submission of the King and the Queen-Mother the object of the expedition had been attained. The great palaver, an account of which appeared in all the papers, is of very recent date, and I shall not therefore describe it, but a few individual descriptions of the chief native personages may be of interest. King Prempeh is a young man of about twenty-eight years of age, of not very intelligent aspect, but with a not disagreeable face. He does not seem to have been of a cruel disposition, but merely dropped in with the hereditary customs of his race as a matter of course. Like all other natives, he was very superstitious, and there is no doubt he was very fond of gin. The priests are said to have exercised great influence over him, and to have counselled war on the occasion of our march up country, a course from which he was only restrained, as $I$ have already stated, by some of his principal chiefs and by the evident disinclination of the people to leave their homes to fight a stronger enemy.

Prempeh is of medium height, naturally well built, but effete from the sedentary nature of his office. $\mathrm{He}$ in this respect offers a strong contrast to his brother, who is a tall, wiry, savage-looking fellow, with dignified bearing and defiant aspect. 
On state occasions the king used to wear a crown which in shape was something like Punch's hat. It was covered with ornaments worked out of gold plate, and behind was a tail with a gold knob, which the people struggled round to touch as he passed through the crowd carried on a chair; but whether they strove to touch the knob through loyalty or through superstition, I cannot say.

In the first preliminary palaver which King Prempeh had with Sir Francis Scott, before the arrival of the Governor, he appeared with a nut in his mouth, so strapped down that he could not speak. This appears to have been in accordance with the native custom, and the rule seems to have a logical reason, inasmuch as it prevents the highest authority from uttering decisive conclusions without due consideration. In conseN quence, the Chief Linguist, or principal adviser of the King, does the $\Xi$ talking, the King approving or otherwise with a vague nod. In native negotiations the King delivers no decisive answer on the spot, خ the official result of his deliberations being rendered later, after due N deliberation with his responsible advisers.

The right-hand man of the King, the Chief Linguist, as he was called, was a chief by name of Kokofuku, and a very fine fellow he was, six feet three inches in height, all muscle and bone, and with a fine deep voice. ${ }_{0}^{\circ} \mathrm{He}$ had visited England, and was one of those who had recognised the $\vec{a}$ uselessness of resistance. One of our officers having asked him in a quiet I moment why the Ashantis had not fought, he candidly replied that our $\approx$ arms were better than theirs, or they would not have allowed us to .. $\mathbb{E}$ enter Kumassi. I think Kokofuku must be a sportsman at heart.

It is said that the real ruler of Ashanti was the Queen-Mother. Judging from the attitude she assumed at the palavers, and from the evident understanding which existed between herself and the Chief Linguist, whom I have just mentioned, it is probable that the assumption is a correct one. A very disagreeable-looking object was this old woman, with a thin bony body and a cruel face, which lips unusually thin for a $D$ native and one long prominent tooth made very repulsive. And indeed her reputation bore out her looks, for rumour speaks of her with an evil tongue. She is credited on good authority with having possessed several dozen Dhusbands, all of whom she had executed, with the sole exception of 'D Prempeh's father. We were informed from a local source that when disIJ pleased she would wipe out her whole suite, and start with a completely fresh retinue; and it was said that changes were frequent, and that the formality of a month's warning was generally dispensed with. In her official capacity as Queen-Mother she was summoned to attend the great palaver before the Governor; but as she, like the King, failed to appear at the appointed hour, both had to be brought up under escort.

I think one of the most comical sights imaginable was that of the Queen-Mother entering the parade ground, shorn of all her state except one umbrella-bearer. As it happened, the escort which flanked her on each side with fixed bayonets consisted of two Yorkshire lads, men of my own detachment. They advanced in strict military attitude, but with a smile on their faces which spoke for all they thought. They had never been so close to a queen before! 
Pity would be wasted on this old hag, the Messalina of Ashanti, who in addition to her other enormities, is credited with having murdered the last king in order that her son Prempeh might come to the throne. She is said, with the aid of Kokofuku, the Chief Linguist whom I have just described, to have forced down the king's throat a piece of chew-stick which he had in his mouth, and to have thus killed him by suffocation. Surely she may be properly called in more senses than one the bête noir of Ashanti.

With the King of Kokofu sitting on a fence and watching the development of events from a distance, the most powerful of the ruling kings, or great chiefs, was the King of Mampon, whose capital is situated some fifty miles north of Kumassi. This chief was said to command 10,000 warriors; but in the tour which the governor subsequently made in the direction of Mampon, this force was not apparent. It is true that their king was at the time accompanying Prempeh, the Queen-Mother, the King's brother, and the Chief Linguist to a castle seven miles from Cape Coast at Elmina, in the dungeons of which in former days the Ashanti kings were wont to imprison their notable captives.

It is doubtful if the King would now be glad to return to his throne from exile, for death is the penalty which an Ashanti king pays for humiliation by the enemy. Shortly after our last war King Kofi was murdered as a consequence of his defeat.

The succession to the throne in Ashanti is regulated in a manner somewhat strange to our ideas. It is not the son of the king that is his heir. The throne is always inherited through a female, passing either to the king's brother or to a nephew (a sister's child), so that there shall be no doubt that the reigning king has royal blood in his veins.

Turning to the principal characteristics of the tribes through whose territories we passed, we found that not much difference was to be noticed between the appearance of the Fantis who live near the coast and the Ashantis inland. Both are physically fine races. The latter possess a less purely negro type than the inhabitants of the coast-line. Their features are somewhat more aquiline, and to our ideas they are handsomer. Both races are intelligent, but in respect of courage the Ashantis are much superior to all their neighbours. The Fantis appear to be a morally run-down race. It is to be feared that in contact with European civilisation their animal spirit has been tamed, whilst they have at the same time failed to gain any compensating moral advantage from the connection. The Ashantis, on the other hand, have always shown themselves to be an untamed and warrior race.

To give the Fanti his due, however, it must be conceded that he did his work as a carrier both honestly and actively, a circumstance for which we were fully grateful. The women make as good carriers as the men, and I fear that in private life the ungallant male part of the population takes only too full an advantage of this quality in the women.

The customs relating to marriage in Ashanti do not, I fear, coincide with European ideas. Polygamy is, of course, universal, but I think that on the whole the people are more moral than might be supposed. The laws of the country are very strict as regards lapses from conjugal duty, 
but the main idea pervading them is evidently one rather of property than of propriety. Thus, there are heavy penalties for the man who tempts a wife. Indeed, it appears only too certain that some of the chiefs make handsome incomes from the penalties extracted for misdemeanours of this nature. The marriage ceremony of the country is of the usual simple and commercial nature amongst savages. The husband pays about $£ 4$ to the parents, and the wife is supposed to be able to regain her liberty at any time by repayment of the purchase price. The husband on his side can make over his wife to another man; and so great is the value of women for work, that the husband has seldom any 6 difficulty in getting a wife off his hands, provided she be young and ¿ strong. E This simple process of divorce does not involve the same difficulty in
respect to children as in civilised countries, for children are bought and $\vec{D}$ sold like any other article, and are early put to labour. Any soil that $\underset{N}{N}$ is cleared will produce at least four crops a year without further trouble ? than the first planting, so it will be understood how great the value $\sim$ of labour, and therefore of women and children, must be. The master F of one or two wives and two or three slaves can be idle from one year's oend to the other.

The religion is, of course, universally fetich, though there exists a small proportion of people of Moorish descent, whose religion is a mixture సี of Mohammedanism and fetichism. The chief business of these people $\sim$ is to make and sell charms which are highly prized. A good many of . pure Ashantis.

The fetich priests form practically a separate caste. They become $\mathcal{U}$ priests by hereditary descent, and are of both sexes. They marry, and

to the children are brought up as fetich-men.
The sacrifices made to fetich, whether they be animal or human, have solely for object the propitiation of the Evil Spirit. I was told that there is no belief in a Good Spirit or in a future life. The missionaries have a wide field of good work here open to them, and soon no doubt Christian missions of various denominations will establish themselves in the country. Before the 1874 expedition a few noble men had braved D the dangers of climate and savage men to preach the Gospel, and had F obtained a footing, but the outbreak of hostilities compelled them to leave before their work had prospered far.

The climate of Ashanti bears a very bad character, which, I think, is well deserved, though probably it is healthier on the whole than the climate of the districts bordering on the coast. Still, there is the forest everywhere, with the unceasing decay of vegetable matter and offensive atmosphere, and there are the malarious swamps in the low grounds. The temperature throughout, even in the hot season, is not excessivegenerally $75^{\circ}$ to $90^{\circ}$ in the daytime. This fact is principally due to the Harmattan, a steady cool breeze which blows from a northerly direction during the winter months, and which is considered so healthy that it is often known as the Doctor. The nights are fairly cool as a rule, but the air is never free from the steaming dampness which weakens the 
European system, and thereby predisposes it to the effects of fever, a malady which in one form or another is bound sooner or later to attack even the strongest European.

The evil effects of the climate in the case of a short stay in the country do not as a rule show themselves until the subject has left the country, and this fact was proved by the small death-roll during the actual stay of the expedition in the country. I need do no more than recall to your mind, in this connection, the sad loss which we sustained in the person of a Prince whom every one admired, and whom every one who met him liked for the genial and simple comradeship which marked his relations with all. Another very sad event, though appealing to the sympathy of a narrower circle, was the death, also through fever, of Major Ferguson of the Life Guards, a distinguished young officer, best known in connection with a mission some years ago to Lobengula, the King of the Matabele.

The water everywhere in the forest is dangerous to drink. Generally it is thick, sometimes stagnant, and as a rule of unpleasant odour. Even in the rare instances when we met with clear water, and this was chiefly in the hilly Moinsi district, it was impossible to be certain that the water was free from evil germs, and the wise precaution of boiling the water was invariably practised. The bad water was filtered, as best it might be, through native calabashes and wood, or precipitated with alum, and the men had ordinary small carbon filters which helped to clear the water; but I should recommend every traveller in these parts to take with him a couple of the best pocket filters. Some of us had the Pasteur filter, which can be procured in all sizes and which has been proved by analysis to almost totally exclude all minute organisms. I used one throughout, and perhaps owe my fortunate immunity from sickness in a large measure to drinking no water which had not passed through this pocket filter.

What the effect of this climate is on vermin insect life I do not know, but we were agreeably surprised to notice an almost total absence of mosquitoes, and the more personal parasites were nowhere visible. Whether the climate is too much even for them I cannot say, but it certainly was strange to notice the conspicuous absence of mosquitoes near the swamps in the hot damp weather presumably so suited to their needs. We saw few snakes, though there are plenty no doubt, and huge forest spiders, centipedes, and scorpions and barracouta rats, though they were seen now and then, kept in their proper places, and appeared, like the Ashantis, to be determined not to molest us.

The ants are a great plague, however, and penetrate everywhere, and . at all times. It is no wonder that the numerous and enormous lizards which run about the walls and courtyards of the houses in the most tame and confident manner should remain unmolested by the natives, for they are the ants' worst enemies, and may be seen darting along the ground all day snapping up victims. They certainly keep the houses almost entirely clear of these small but persistent pests. Of bigger animals we saw nothing, as of course the unusual human activity along the paths drove them into the far recesses of the forest. The natives trap the leopards 
and kill the monkeys for their skins, and there are said to exist huge pythons, but they too kept at a discreet distance.

I would now, in conclusion, endeavour to briefly expose the results gained by the success of the recent expedition.

There is first the sentimental but important question of the abolition of human sacrifice and cruelty in this dark corner of the dark continent. The principal advantage gained has, however, been the opening of the trade route to the interior of Africa, and a reference to the map will show that the road through Ashanti is the most direct route from the Gold Coast to Timbuctoo. When a good road shall have been laid through 6 Kumassi and Mampon to the fertile plains which lie to the north of Ashanti, a new and vast field will be opened to the enterprise of British commerce, and Gold Coast Colony, which paid the piper for the recent Eampaign, should soon earn a rich return for its expenditure. It may be expected that a flourishing trade will be opened with these regions, and $\underset{N}{N}$ that in exchange for our goods we shall draw to the coast, amongst other objects of trade, indiarubber, ivory, skins, kola-nuts and palm-oil, and gold.

Ashanti itself, once such a remunerative field for British commerce, F will now be opened up again to our trade.

As regards the question of gold, it is impossible so far to say what Oresources of the precious metal the country may possess; but that alluvial gold is to be found in many places is certain, and many Europeans have E come across the deserted holes three feet or so deep which the natives Shave worked with success to this-to them-convenient depth. In the hills, as well as on some of the higher ground, promising-looking quartz, including the white variety, was reported by qualified persons. However that may be, the question of the dreadful climate must always seriously Uprejudice the sustained working of mines by Europeans. Still, where the o god Mammon offers rewards, votaries will always be found to worship Bhim, at whatever risk, and possibly extensive clearings and drainage, and precautions as regards water and other sources of disease, may make certain districts more habitable. There are no serious engineering difficulties to be surmounted from the coast to Kumassi in view of the ${ }_{\text {construction of roads or light railways; but it must not be forgotten }}$ othat, owing to the extent and character of the great forest and the Ejphenomenal growth of all vegetable life, it can never be cleared to any Tappreciable degree. The luxuriant tropical growth must ever remain as an enemy to health and an obstacle to any extensive agricultural odevelopment.

In view of the importance to British trade of the countries forming the Hinterland of Ashanti, I beg to present to you a few notes on them drawn from information procured from the most recent reports by English travellers in this region.

The principal territories directly inland of the colony are Gonja, Dagomba, Gruma, Gaman, Gurnshi, and Mosi, With these Lobi, Bona, Male or Chakosi, Pampamba, Bimbla, Borgu, Busiansi, and Massina have trade and political intercourse. With the exception of Massina, they lie more or less in the area watered by the Volta and its tributaries, between the Gold Coast Colony on the south and the Middle Niger on 
the north. A range of hills stretching NNE. and SSW., called Boosu, is the eastern boundary of the area of the Volta.

The resources of the countries just mentioned are said to consist of gold in the western districts of Gaman, Lobi, and in branches of the Kong Mountains ; ivory, horses, cattle, and slaves, brought down from Mosi and the region of the Middle Niger; shea-butter fruit, the pro. ducing tree growing abundantly in the plains; gum arabic, produced in enormous quantities in the plains, but which at present does not form an article of export to any extent. The plains afford pasture to cattle, sheep, and horses. Rice, guinea-corn, millet, and other cereals, as well as ground-nut, sweet potato, and cassava, grow luxuriantly in the rich plains. The people cultivate indigo, tobacco, and cotton.

A peculiar disease is said to afflict the cattle in epidemic form, and kills large numbers of them.

As regards articles of trade-silver, glass armlets, knives, powder, flints, Madras handkerchiefs, rum, gin, beads, grey baft, swords, and fishhooks are accepted in exchange by the people for cowries, ivory, gold, cattle, and slaves. A slave is worth between $£ 3$ and $£ 7$ in Salagha, and the following are said to be the usual prices of some of the articles sold there, in shillings and decimals of a shilling :-

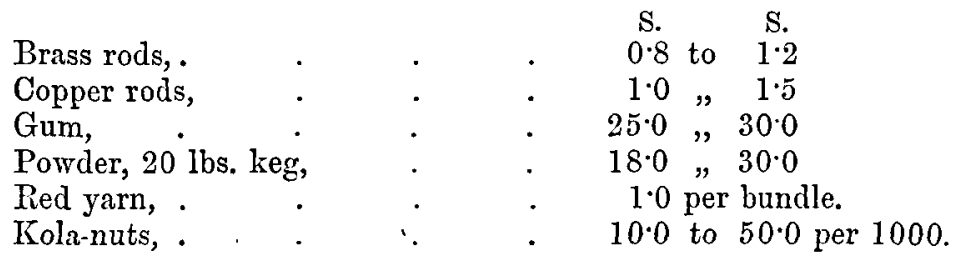

The price of gold at Bona is $£ 2$ an ounce, as against $£ 3,12 \mathrm{~s}$. 6 d. on the coast.

Cowries used as currency are the local medium of exchange, 1000 being reckoned as worth a shilling.

Cotton goods for native trade must be thick in texture, good in quality, and low in price to replace the native manufacture, though the present ordinary trade kind is largely used for native garments. Traders must be ready to deal with the tolls exacted by the native authorities, as well as with the restrictions of the middlemen, on a satisfactory basis.

Ordinary travellers can cover on an average fourteen miles a day, but caravans travel more slowly, eight to ten miles a day being the usual distance.

The cost of transport through the forest kingdom of Ashanti to the plains of the Hinterland is $£ 9$ to $£ 10$ per ton for every sixty miles. The proper load for a carrier is about $60 \mathrm{lbs}$.

The ground-rock is principally sandstone. Eruptive rocks are abundant, but not many schistose rocks are to be seen. There are indications in some parts, however, of clay-slate, quartzite, etc. Salt is made at Daboya from the alluvium on the right river bank of the Volta, and rock-salt is reported from the Pampamba country. Nitre has been observed at Bole and Massina. West of the main Volta gold is 
said to be abundant; and Lobi, rich in that mineral, is noted for the largeness of its nuggets.

To the east of the main Volta clay ironstone has frequently been observed, but the deposit is reported as not persistent over a wide area. The ore is, however, smelted in parts of Dagomba, Pampamba, Buem Kotokori, Gruma, and Mosi. The smelting is carried on with great secrecy; charcoal is obtained by burning a particular kind of wood, and blast is afforded by means of two leather bags made of goat's skin with a common orifice. The iron produced (generally soft and white, though a superior variety is occasionally obtained) supplies the material o for forging arrowheads, spears, knives, and other small iron-work.

The geological formation on the west and north is composed chiefly of crystalline rocks, while Palæozoic sandstones and shales occupy the ङ south and east. The middle portion has a plateau 1200 feet high, trend$\vec{a}$ ing roughly north-west and south-east.

From the inquiries of travellers in the more interior countries of ? Gando and Mosi, there appears to be an analogy and probable synchronism $m$ of the geological formation of the Gold Coast Colony with the more $\approx$ inland territories.

The physical aspect of these districts is reported as generally undulating plain, with tall, coarse, reedy grass in the countries south of $8^{\circ} 30^{\prime}$, spreading southwards into and terminating in the forest region of the ₹ Colony. Northwards the grass is more or less turf-like in character, with trees scattered singly and in clumps, treeless tracts being occasionally met with. The vegetation of the river banks is, however, denser, and the whole region affords room and food for the elephant, hippopotamus, deer, buffalo, and other animals. Lions exist in considerable numbers.

The plains afford facilities for transport by animals (generally horses and donkeys, but rarely camels), of goods brought down by caravans from the Mosi and Houssa countries, which travel from November to February. The whole region is said to be healthy.

The rains in these countries are said to be very heavy in September and October, the rivers reaching their highest water-level about the beginning of November. The natives possess notions about rain-making $\vec{a}$ and rain-stopping corresponding to those ascertained by Livingstone to Dexist among other tribes of the interior of Africa.

The King of Dagomba is the most influential potentate in this district. In the days of extended Ashanti power, he furnished an annual tribute of one thousand slaves to the Ashanti king, and he was called by the Ashantis the Rich King. Between Dagomba and Mosi there is a belt of inhospitable barbarous tribes, through which caravans often have to force their way. The Mosi are a warlike tribe, and are for the greater part vassals of the King of Wagadugu. The old long Dane guns carried into Mosi, and those countries which use large numbers of horses, are shortened by cutting off a portion of the barrel and stock to adapt them for cavalry use.

In conclusion, I regret that I am precluded from dealing, even in a general way, with the political aspect and future of the rich countries which form the Hinterland of Ashanti. I may, however, state that, in 
the complicated negotiations which are at present being conducted by the three great colonising Powers of Europe regarding the partition of this portion of Africa, the interests of Great Britain are being carefully watched.

\section{THE IGNEOUS ROCKS OF THE CAUCASUS.}

\section{By V. Dingelstedt, Corr. Member.}

BEFORE treating of my special subject, indicated above, I may say a few words about the geological study of the Caucasus. The Caucasian mountains have not as yet attracted the attention of geologists in a degree corresponding to their real importance in the history of the formation of the earth's crust. There is but little record to be found in English geological literature concerning this extensive mountainous country, and whilst in every English text-book of geology important references are made to the geology of almost every other part of the earth's surface, there is comparatively little said about the Caucasus. The reason of this is certainly not to be found in lack of interest in the subject, but rather in the inaccessibility of the Russian language, and perhaps also in defective research and the scarcity of the positive results as yet obtained in the country, to which I would now draw the attention of the reader. I have already had occasion, in a description of Svanetia, to speak of the unfavourable conditions of such a country as the Caucasus for scientific research, and $I$ have only to add now that geological studies, on account of their special character, requiring as they do great physical exertion, inuch courage, and varied knowledge, can only be pursued here under enormous difficulties. I do not imply, however, that this kind of study does not make some advance. Thanks to the efforts of the Government, a Board of Mining Engineers has been established for the purpose of prosecuting geological investigations independently of their proper task of controlling and supervising the exploitation of metallic ores, and an eminent geologist and palæontologist, M. Abich, has been engaged, also at the cost of the Government, who has worked indefatigably and with considerable success for many years. The Russian and German geological literature (M. Abich having written in German) is therefore not inconsiderable, and it is really to be regretted that, with the exception of a geological map of the Caucasus, recently published in The Exploration of the Caucasus, by D. W. Freshfield, and accompanied by a sketch of the geology of the country by Professor. Bonney, there is little information on the subject printed in English.

I do not propose in the present paper to pass in review the whole geology of the country as at present known, discussing the ages of the strata forming the vast mountainous country between the Black Sea and the Caspian Sea, their stratigraphical or tectonical disposition, or their lithological character, but only to give an account of what is actually known concerning the igneous rocks in the Caucasus. Having supplied material for the sedimentary or clastic rocks of all 